\title{
Predictive Value of Pretransplant Serum Lactate Dehydrogenase (LDH) Levels for Survival in Patients who have undergone Allogeneic Hematopoietic Stem Cell Transplantation (alloHSCT)
}

Serdar Sivgin ${ }^{1 *}$, Tahsin Ozenmis², Leylagul Kaynar¹, Fatih Kurnaz ${ }^{1}$, Hulya Sivgin ${ }^{3}$, Suleyman Baldane ${ }^{1}$, Gokmen Zararsız ${ }^{4}$, Bulent Eser ${ }^{1}$, Ali Unal ${ }^{1}$ and Mustafa Cetin ${ }^{1}$

${ }^{1}$ Dedeman Stem Cell Transplantation Hospital, Department of Hematology, Erciyes University, Kayseri, Turkey

${ }^{2}$ Department of Internal Medicine, Erciyes University, Kayseri, Turkey

${ }^{3}$ Department of Medical Genetics, Erciyes University, Kayseri, Turkey

${ }^{4}$ Department of Biostatistics; Faculty of Medicine, Erciyes University, Kayseri, Turkey

\begin{abstract}
Objectives and aim: Our objective was to investigate the association of pre-transplant Lactate Dehydrogenase (LDH) levels with complications and survival following allogeneic Hematopoietic Stem Cell transplantation (alloHSCT).

Materials and methods: We retrospectively analyzed data of 156 patients who had undergone alloHSCT from 2004 to 2010 in Dedeman Stem Cell Transplantation Hospital, Kayseri, Turkey. Pretransplant serum lactate dehydrogenase (LDH), alkaline phosphatase (ALP), creatinin and fibrinogen levels drawn within 7 days prior to transplantation were analyzed with data of transplant procedures.

Results: 63 (40.3\%) of the patients were female, while $93(59.7 \%)$ were male. The median age was 26 years (min-max:13-57). The median pretransplant serum levels of; LDH was 202U/L (min-max: 71-1202), alkaline phosphatase 83.0 U/L (min-max: 21-379), creatinin 0.70mg/dL (min-max: 0.30-2.40), and fibrinogen 293mg/dL (minmax: 7.0-566.0); respectively. Univariate and multivariate analysis showed that high pre-transplant LDH levels ( $\geq$ $246 \mathrm{ng} / \mathrm{mL}$ ) were significantly correlated with decreased disease-free survival (DFS) rates $(p=0.037)$. A higher risk of death was observed in high LDH group both in univariate and multivariate analysis (hazard ratio=2.27, Cl: 1.06-3.57 and hazard ratio=1.94, $\mathrm{Cl}: 1.06-3.57$; respectively). In univariate analysis; although there was a correlation between high serum LDH levels and decreased rates of OS, this was not statistically significant (hazard ratio $=1.31, \mathrm{Cl}: 0.80$ $2.13, p=0.286$ ). There was no statistically significant difference among groups for the parameters ALP, creatinin, CD $34^{+}$cell count, age, gender and diagnosis $(p>0.05)$.
\end{abstract}

Conclusion: Pre-transplant increased serum LDH levels may be associated with poor survival in patients who have undergone allogeneic hematopoietic stem cell transplantation.

Keywords: Allogeneic hematopoietic stem cell transplantation; LDH; Prognosis; Survival

\section{Introduction}

Allogeneic hematopoietic stem cell transplantation (alloHSCT) is considered as a curative treatment for various hematologic malignancies. Although improvement of the outcome has been achieved in recent decades, infectious complications, GVHD and transplant-related complications remain importance for transplant-related mortality $[1,2]$. Recently, efforts have been directed to determine the prognostic markers of HSCT which could be used prior to transplantation. Many studies have established some parameters which could be regarded to have prognostic value in alloHSCT recipients. Ferritin is widely studied for outcomes prior to transplantation in the last decade for many physicians [3-5]. Several different mechanisms may underly an increase in $\mathrm{LDH}$ in hematological malignancies including Myelodysplastic Syndrome (MDS), lymphomas and leukemias. One possible factor may be the increased turnover and degradation of myeloid cells in the Bone Marrow (BM), spleen, and other tissues. Among the other possible mechanisms; ineffective hematopoiesis could be encountered. Additional cofactors may be an infiltration of the liver and spleen by immature myeloid cells or iron overload.

Serum LDH levels have been shown to indicate hypoxic status associated with tumor cells and as a result, high serum levels were found to be correlated with worse prognosis. LDH levels have been evaluated as predictive marker in various malignancies including non-Hodgkin lymphomas [6], germ cell tumors [7] and small cell lung cancer [8]. As a general consideration, high levels of LDH are mostly found in heart, liver, erythrocytes, skeletal muscles and kidneys. Although high levels of LDH are known to be associated with poor prognosis in both children and adults with lymphoma $[9,10,11]$, its significance in patients who had undergone alloHSCT still remains unclear. The analysis of pretransplant serum LDH is considerably easy and unexpensive method so, this might be used to show patients with high risk prior to the transplantation.

This study aimed to determine the prognostic significance of pretransplant serum LDH levels for survival in alloHSCT recipients regardless to the primary diagnosis.

*Corresponding author: Serdar Sivgin, Dedeman Stem Cell Transplantation Hospital, Department of Hematology, Faculty of Medicine, Erciyes University, Kayseri, Turkey, Tel: +903522076666; Fax:+903524379348; E- Mail: serdarsvgn@gmail.com

Received March 30, 2012; Accepted April 16, 2012; Published April 18, 2012

Citation: Sivgin S, Ozenmis T, Kaynar L, Kurnaz F, Sivgin H, et al. (2012) Predictive Value of Pretransplant Serum Lactate Dehydrogenase (LDH) Levels for Survival in Patients who have undergone Allogeneic Hematopoietic Stem Cell Transplantation (alloHSCT). J Stem Cell Res Ther 2:118. doi:10.4172/2157-7633.1000118

Copyright: (C) 2012 Sivgin S, et al. This is an open-access article distributed under the terms of the Creative Commons Attribution License, which permits unrestricted use, distribution, and reproduction in any medium, provided the original author and source are credited. 
Citation: Sivgin S, Ozenmis T, Kaynar L, Kurnaz F, Sivgin H, et al. (2012) Predictive Value of Pretransplant Serum Lactate Dehydrogenase (LDH) Levels for Survival in Patients who have undergone Allogeneic Hematopoietic Stem Cell Transplantation (alloHSCT). J Stem Cell Res Ther 2:118. doi:10.4172/2157-7633.1000118

Page 2 of 5

\section{Patients and Methods}

A total of 156 patients who had undergone alloHSCT between April 2004 and May 2010 at Dedeman Stem Cell Transplantation Hospital, Faculty of Medicine, Erciyes University, Kayseri, Turkey; were analyzed retrospectively. The data was obtained from the patient's records. A pretransplantation serum $\mathrm{LDH}$, fibrinogen, creatinin and alkaline phosphatase levels drawn within 7 days prior to transplantation were available for 156 patients. Patients who had lack of data, active inflammatory or infectious disease and active hemolytic disease were excluded from the study. The patients were divided into two groups; patients with normal levels for each parameter (Group 1) and patients with abnormal levels (Group 2). Overall survival (OS) was defined as the time between transplantation and death (from any cause) or last follow-up. Time-to-transplant interval was designed as HSCT before and after 1 year of diagnosis. Engraftment was defined, for platelet engrafment, as the day on which platelet count exceeds $20000 / \mathrm{mm}^{3}$ and for neutrophil engraftment the day on which neutrophil count exceeds $500 / \mathrm{mm}^{3}$ for at least 3 days consecutively. Informed consent forms were obtained from all patients prior to the transplantation. This study was approved by the ethic committee of Erciyes University.

\section{Statistical Analysis}

In statistical analysis, we used Mann-Whitney U test for continuous variables between the 2 groups. Possible risk factors were tested using the log rank test and the Cox regression model. The calculations were performed using commercially available software (SPSS version 15.0; SPSS Inc, Chicago, Illinois). Numerical variables are summarized by their medians and ranges, categorical variables by counts and relative frequencies. Overall survival (OS) and Disease Free-Survival (DFS) were calculated using the Kaplan-Meier method. Univariate and multivariate survival analyses were performed using Cox proportional hazards regression to identify the most significant independent prognostic factors. Variables significant at $\mathrm{p}<0.25$ level on univariate analysis were included in a multivariate model and backward stepwise selection was performed at a stringency level of $\mathrm{p}<0.10$ to determine the independent risk factors. Odds ratios are also given with the $95 \%$ confidence intervals.

\section{Results}

A total of 156 patients who underwent alloHSCT were retrospectively analyzed. 63 (40.3\%) of the patients were female, while $93(59.7 \%)$ were male. The diagnosis of the patients were; patients with AML $(68,43.5 \%)$, ALL $(38,24.3 \%)$, aplastic anemia $(18,11.5 \%)$, lymphomas $(16,10.3 \%)$, chronic myelogenous leukemia $(6,3.8 \%)$, and others $(12,7.6 \%)$. The median age was 26 years (min-max: 13-57). The conditioning regimens were; $\mathrm{Bu} / \mathrm{Cy}$ in 77 (49.3\%), TBI/Cy in 21 (13.5\%), ATG/Flu/Cy in 16 (10.3\%), Flu/Cy in 12 (7.7\%), ATG/Flu/ $\mathrm{Bu}$ in $9(5.7 \%)$ and other regimens in $21(13.5 \%)$ of the patients. The patient characteristics are listed in Table 1.

The median pretransplant serum levels of; LDH was 202U/L (minmax: 71-1202), alkaline phosphatase $83.0 \mathrm{U} / \mathrm{L}$ (min-max: 21-379), creatinin $0.70 \mathrm{mg} / \mathrm{dL}$ (min-max: $0.30-2.40$ ), and fibrinogen $293 \mathrm{mg} / \mathrm{dL}$ (min-max: 7.0-566.0); respectively. The median platelet engraftment day in group 1 was found 11 (min-max: 6-30) and neutrophil engraftment day 14 (min-max: 9-40). In group 2; the median platelet engraftment day was found 10 (min-max: 7-30) and neutrophil engraftment day 14 (min-max: 8-30).

\begin{tabular}{|c|c|c|c|}
\hline Variables & $\begin{array}{c}\text { Patients with } \\
\text { LDH<246 } \\
\text { Group } 1 \\
\text { N=102\% }\end{array}$ & $\begin{array}{l}\text { Patients with } \\
\text { LDH } \geq 246 \\
\text { Group } 2 \\
\\
\mathrm{~N}=54 \%\end{array}$ & $\begin{array}{c}\text { Total (156) } \\
\text { N\% }\end{array}$ \\
\hline $\begin{array}{l}\text { Median age } \\
\text { years (min-max) }\end{array}$ & $26.5(13-57)$ & $25.5(15-52)$ & $26.0(13-57)$ \\
\hline $\begin{array}{l}\text { Gender } \\
\text { female } \\
\text { male }\end{array}$ & $\begin{array}{l}42(41.2) \\
60(58.8)\end{array}$ & $\begin{array}{l}21(38.9) \\
33(61.1)\end{array}$ & $\begin{array}{l}63(40.3) \\
93(59.7)\end{array}$ \\
\hline $\begin{array}{l}\text { Diagnosis } \\
\text { AML } \\
\text { ALL } \\
\text { CML } \\
\text { AA } \\
\text { Lymphoma } \\
\text { Others }\end{array}$ & $\begin{array}{c}43(42.2) \\
25(24.5) \\
4(3.9) \\
14(13.7) \\
10(9.8) \\
6(5.9)\end{array}$ & $\begin{array}{c}23(42.6) \\
13(24.1) \\
2(3.7) \\
4(7.4) \\
6(11.1) \\
6(11.1)\end{array}$ & $\begin{array}{c}68(43.5) \\
38(24.3) \\
6(3.8) \\
18(11.5) \\
16(10.3) \\
12(7.6)\end{array}$ \\
\hline $\begin{array}{l}\text { Acute GVHD } \\
\text { Yes } \\
\text { No }\end{array}$ & $\begin{array}{l}20(19.6) \\
82(80.4)\end{array}$ & $\begin{array}{l}13(24.1) \\
41(75.9)\end{array}$ & $\begin{array}{c}33(21.1) \\
123(78.9)\end{array}$ \\
\hline $\begin{array}{l}\text { Chronic GVHD } \\
\text { Yes } \\
\text { No }\end{array}$ & $\begin{array}{l}38(37.3) \\
64(62.7)\end{array}$ & $\begin{array}{l}20(37.0) \\
34(63.0)\end{array}$ & $\begin{array}{l}58(37.1) \\
98(62.9)\end{array}$ \\
\hline $\begin{array}{l}\text { Disease status } \\
\text { at tx } \\
\text { CR1 } \\
\text { CR2 } \\
\text { Active disease }\end{array}$ & $\begin{array}{c}90(88.3) \\
4(3.9) \\
8(7.8)\end{array}$ & $\begin{array}{c}45(83.3) \\
3(5.6) \\
6(11.1)\end{array}$ & $\begin{array}{c}135(86.5) \\
7(4.6) \\
14(8.9)\end{array}$ \\
\hline $\mathrm{CD} 4^{+}\left(10^{6} / \mathrm{kg}\right)$ & $6.9(4-19)$ & $6.7(3-14)$ & \\
\hline $\begin{array}{l}\text { Preparative } \\
\text { regimen } \\
\text { Bu/Cy } \\
\text { TBI/Cy } \\
\text { ATG/Flu/Cy } \\
\text { ATG/Flu/Bu } \\
\text { Flu/Cy } \\
\text { Others }\end{array}$ & $\begin{array}{c}52(51.0) \\
14(13.7) \\
12(11.8) \\
3(2.9) \\
9(8.8) \\
12(11.8)\end{array}$ & $\begin{array}{c}25(46.3) \\
7(13.0) \\
4(7.4) \\
6(11.1) \\
3(5.6) \\
9(7.6)\end{array}$ & $\begin{array}{c}77(49.3) \\
21(13.5) \\
16(10.3) \\
9(5.7) \\
12(7.7) \\
21(13.5)\end{array}$ \\
\hline $\begin{array}{l}\text { HLA match } \\
\text { full-match } \\
\geq 1 \text { miss-match } \\
\text { Unrelated }\end{array}$ & $\begin{array}{c}90(88.2) \\
11(10.8) \\
1(1.0)\end{array}$ & $\begin{array}{c}44(81.5) \\
8(14.8) \\
2(3.7)\end{array}$ & $\begin{array}{c}134(85.9) \\
19(12.1) \\
3(2.0)\end{array}$ \\
\hline $\begin{array}{l}\text { Median interval to } \\
\text { tx (months) } \\
<12 \text { months } \\
>12 \text { months }\end{array}$ & $\begin{array}{l}69(67.6) \\
33(32.4)\end{array}$ & $\begin{array}{l}37(68.5) \\
17(31.5)\end{array}$ & $\begin{array}{l}106(78.0) \\
50(22.0)\end{array}$ \\
\hline $\begin{array}{l}\text { Graft source } \\
\text { PBSC } \\
\text { BM }\end{array}$ & $\begin{array}{c}102(100) \\
0\end{array}$ & $\begin{array}{c}54(100) \\
0\end{array}$ & $\begin{array}{c}156(100) \\
0\end{array}$ \\
\hline $\begin{array}{l}\text { Gender match } \\
\text { matched } \\
\text { mismatched }\end{array}$ & $\begin{array}{l}76(74.5) \\
26(25.5)\end{array}$ & $\begin{array}{l}35(64.8) \\
19(35.2)\end{array}$ & $\begin{array}{l}111(71.1) \\
45(28.9)\end{array}$ \\
\hline
\end{tabular}

Table 1: Patient characteristics.

In the posttransplant evaluation; infections were the leading complication in the recipients. $112(71.8 \%)$ of the patients had at least $\geq 1$ episode of infectious events. Most of the infections were bacterial (45.5\%), fungal (20.5\%) and viral (8.9\%); respectively. Sites of infections were found as; pulmonary (41.4\%), mucositis (16.6\%), catheter-related (12.4\%), urinary system infections (11.6\%) and others (18\%). GVHD was the second common complication in the posttransplant period. A total of $33(21.2 \%)$ patients had acute GVHD while chronic GVHD was diagnosed in $58(37.2 \%)$ of the patients. 8 (5.1\%) of the patients with acute GVHD had already diagnosed with chronic GVHD.

\section{Relapse and mortality}

Of the patients; 42 (26.9\%) had relapsed during follow-up. 22 (21.6\%) of them were in group 1 and 20 (37.0\%) of them were in group 
Citation: Sivgin S, Ozenmis T, Kaynar L, Kurnaz F, Sivgin H, et al. (2012) Predictive Value of Pretransplant Serum Lactate Dehydrogenase (LDH) Levels for Survival in Patients who have undergone Allogeneic Hematopoietic Stem Cell Transplantation (alloHSCT). J Stem Cell Res Ther 2:118. doi:10.4172/2157-7633.1000118

Page 3 of 5

2. In group 1; $40(39.3 \%)$ of 102 patients died, while in group 2, 27 $(50.0 \%)$ of 54 patients died. A total of $3(2.9 \%)$ patients in group 1 and $2(3.7 \%)$ patients in group 2 died within 100 days of alloHSCT. The leading causes of mortality were; relapsed disease (37.3\%), infections (31.3\%) and GVHD (22.3\%). Univariate and multivariate analysis showed that high pre-transplant $\mathrm{LDH}$ levels ( $\geq 246 \mathrm{ng} / \mathrm{mL}$ ) were correlated with decreased disease-free survival (DFS) rates $(\mathrm{p}=0.037)$. A higher risk of death was observed in high LDH group both in univariate and multivariate analysis (hazard ratio $=2.27, \mathrm{CI}: 1.06-3.57$ and hazard ratio=1.94, CI: 1.06-3.57; respectively). In univariate analysis; although there was a correlation between high serum LDH levels and decreased rates of OS, it was not statistically significant (hazard ratio=1.31, CI: $0.80-2.13, \mathrm{p}=0.286$ ). Survival analyses are shown in Table 2 and Table 3.

There was no statistically significant difference among groups for the parameters ALP, creatinin, $\mathrm{CD} 34^{+}$cell count, age, gender and diagnosis $(\mathrm{p}>0.05)$. In univariate analysis; there was a positive correlation in the late HSCT group ( $>12$ months) for decreased OS and DFS, but this was not statistically significant (HR: 1.58, CI: 0.97-2.56 and HR: 1.67, CI: 0.91-3.09, respectively). In multivariate analysis, it was found that early HSCT ( $<12$ months) was significantly correlated with improved OS (HR: 1.85, CI: 1.12-3.07 and $\mathrm{p}=0.017$ ).

\section{Discussion}

Lactate Dehydrogenase (LDH) enzyme catalyzes reversible transformation of pyruvic acid to lactic acid under anaerobic conditions. As a result, induction of anaerobic glycolysis serves as an important

\begin{tabular}{|c|c|c|c|c|}
\hline \multirow[b]{2}{*}{ Variables } & \multicolumn{3}{|c|}{ os } & \multirow[b]{2}{*}{$\mathrm{p}$} \\
\hline & $\begin{array}{l}\text { Univarite } \\
\mathrm{HR}(95 \% \mathrm{Cl})\end{array}$ & $\mathbf{p}$ & $\begin{array}{l}\text { Multivariate } \\
\mathrm{HR}(95 \% \mathrm{CI})\end{array}$ & \\
\hline $\begin{array}{l}\text { LDH } \\
(<246 / \geq 246)\end{array}$ & $1.31(0.80-2.13)$ & 0.286 & - & - \\
\hline $\begin{array}{l}\text { Age } \\
(<40 / \geq 40)\end{array}$ & $0.74(0.38-1.46)$ & 0.390 & - & - \\
\hline $\begin{array}{l}\text { Gender } \\
\text { (Male / female) }\end{array}$ & $1.12(0.69-1.82)$ & 0.653 & - & - \\
\hline $\begin{array}{l}\mathbf{A L P}( \\
(<129 / \geq 129)\end{array}$ & $1.09(0.63-1.89)$ & 0.755 & - & - \\
\hline $\begin{array}{l}\text { Creatinin } \\
(<1.3 / \geq 1.3)\end{array}$ & $0.98(0.24-4.01)$ & 0.744 & - & - \\
\hline $\begin{array}{l}\text { Fibrinogen group } \\
(<400 / \geq 400)\end{array}$ & $1.17(0.65-2.10)$ & 0.601 & - & - \\
\hline $\begin{array}{l}\text { Donor status } \\
\text { (gender match / } \\
\text { gender mismatch) }\end{array}$ & $1.27(0.77-2.11)$ & 0.351 & - & - \\
\hline $\begin{array}{l}\text { Diagnosis } \\
\text { (Acute leukemia / } \\
\text { Others) }\end{array}$ & $0.99(0.52-1.88)$ & 0.984 & - & - \\
\hline $\begin{array}{l}\text { Time -to-tx } \\
\text { interval (months } \\
(<12 \text { months / } \\
>12 \text { months) }\end{array}$ & $1.58(0.97-2.56)$ & 0.06 & $1.85(1.12-3.07)$ & 0.017 \\
\hline $\begin{array}{l}\text { HLA match } \\
\text { (full match / } \geq 1 \\
\text { mismatch) }\end{array}$ & $1.70(0.90-3.20)$ & 0.101 & - & - \\
\hline $\begin{array}{l}\text { Conditioning } \\
\text { regimen } \\
\text { (Myeloablative } \\
\text { Nonmyeloablative) }\end{array}$ & $1.37(0.82-2.29)$ & 0.226 & - & - \\
\hline $\begin{array}{l}\text { CD34 }{ }^{+} \text {group } \\
\left(<8 />8\left(10^{6} / \mathrm{kg}\right)\right)\end{array}$ & $0.69(0.34-1.39)$ & 0.297 & - & - \\
\hline
\end{tabular}

Table 2: Univariate and multivariate analysis of parameters for overall survival (OS).

\begin{tabular}{|c|c|c|c|c|}
\hline \multirow[b]{2}{*}{ Variables } & \multirow[b]{2}{*}{$\begin{array}{l}\text { Univarite } \\
\mathrm{HR}(95 \% \mathrm{Cl}\end{array}$} & \multirow[b]{2}{*}{ p } & DFS & \multirow[b]{2}{*}{$\mathbf{p}$} \\
\hline & & & $\begin{array}{l}\text { Multivariate } \\
\mathrm{HR}(95 \% \mathrm{Cl})\end{array}$ & \\
\hline $\begin{array}{l}\text { LDH } \\
(<246 / \geq 246)\end{array}$ & $1.95(1.06-3.57)$ & 0.032 & 1.94(1.06-3.57) & 0.032 \\
\hline $\begin{array}{l}\text { Age } \\
(<40 / \geq 40)\end{array}$ & $0.87(0.39-1.96)$ & 0.738 & - & - \\
\hline $\begin{array}{l}\text { Gender } \\
\text { (Male / female) }\end{array}$ & $1.74(0.95-3.19)$ & 0.074 & $1.74(0.95-3.19)$ & 0.075 \\
\hline $\begin{array}{l}\text { ALP } \\
(<129 / \geq 129)\end{array}$ & $1.04(0.52-2.08)$ & 0.909 & - & - \\
\hline $\begin{array}{l}\text { Creatinin } \\
(<1.3 / \geq 1.3)\end{array}$ & $0.72(0.10-5.22)$ & 0.764 & - & - \\
\hline $\begin{array}{l}\text { Fibrinogen group } \\
(<400 / \geq 400)\end{array}$ & $1.05(0.50-2.23)$ & 0.892 & - & - \\
\hline $\begin{array}{l}\text { Donor status } \\
\text { (gender match / gender } \\
\text { mismatch) }\end{array}$ & $1.03(0.53-2.02)$ & 0.931 & - & - \\
\hline $\begin{array}{l}\text { Diagnosis } \\
\text { (Acute leukemia / Others) }\end{array}$ & $1.27(0.64-2.54)$ & 0.485 & - & - \\
\hline $\begin{array}{l}\text { Time -to-tx interval } \\
\text { (months } \\
\text { (<12months / >12months) }\end{array}$ & $1.67(0.91-3.09)$ & 0.100 & - & - \\
\hline $\begin{array}{l}\text { HLA match } \\
\text { (full match / } \geq 1 \text { mismatch) }\end{array}$ & $1.17(0.49-2.78)$ & 0.731 & - & - \\
\hline $\begin{array}{l}\text { Conditioning regimen } \\
\text { (Myeloablative / } \\
\text { Nonmyeloablative) }\end{array}$ & $1.43(0.75-2.73)$ & 0.280 & - & - \\
\hline $\begin{array}{l}\text { CD34+ group } \\
\left(<8 />8\left(10^{6} / \mathrm{kg}\right)\right)\end{array}$ & $0.63(0.26-1.54)$ & 0.311 & - & - \\
\hline
\end{tabular}

Table 3: Univariate and multivariate analysis of parameters for disease-free survival (DFS).

step for both normal cells and cancer cells that need to survive [11]. Today we know that serum LDH levels have been considered to indicate hypoxic status associated with tumor cells and as a result, high serum levels were found to be correlated with worse prognosis due to high tumor burden and metatstatic disease [12]. In clinical practice, serum $\mathrm{LDH}$ is consered as a general indicator of tissue damage in health and disease [13]. Wimazal et al. [14] showed that LDH could be an interesting follow-up parameter in MDS, which might assist in early recognition of disease progression and thus help in risk stratification and patient selection for interventional therapies. In the study; LDH levels were determined in 221 patients with de novo MDS (median age 70 years, range 24-94). The increase in $\mathrm{LDH}$ was found correlated with survival and Acute Myeloid Leukemia (AML) evolution.

A number of different factors may contribute to an increase in LDH. Apart from a transient increase in LDH seen in infectious (viral) diseases or hemolysis, patients with MDS may also develop a Paroxysmal Nocturnal Hemoglobinuria (PNH) subclone or hepatopathy (iron overload) with increase in $\mathrm{LDH}[15,16]$. Recently Mehta et al. [17] showed that that younger donor age was associated with better outcome after submyeloablative allogeneic hematopoietic stem cell transplantation (HSCT) for hematologic malignancies due to lower TRM and relapse. Also, they found that poor performance status, donor age $>45$ years and elevated lactate dehydrogenase (LDH) increased the risk of treatment-related mortality (TRM), refractory disease and donor age $>45$ years increased the risk of relapse, and OS and DFS were adversely influenced by refractory disease, poor performance status, increased $\mathrm{LDH}$, and donor age $>45$ years. 
Citation: Sivgin S, Ozenmis T, Kaynar L, Kurnaz F, Sivgin H, et al. (2012) Predictive Value of Pretransplant Serum Lactate Dehydrogenase (LDH) Levels for Survival in Patients who have undergone Allogeneic Hematopoietic Stem Cell Transplantation (alloHSCT). J Stem Cell Res Ther 2:118. doi:10.4172/2157-7633.1000118

Page 4 of 5

In a previous study [18]; it was demonstrated that there was a significant correlation between expression of $\mathrm{LDH}$ and proliferative activity of cells. Therefore, we supposed that an elevated LDH levels prior to alloHSCT may be associated with cell proliferation and damage, so an elevated LDH level may reflect the probable risks for prognosis in the posttransplant period. Diseases affecting liver, heart, skeletal muscles and kidneys may result in elevations in total serum LDH levels which may lead physicians to make differential diagnosis prior to HSCT. However; we are routinely performing laboratory analysis for excluding any inflammatory or infectious diseases before the transplantation procedure.

Beltran et al. [19] showed that high LDH levels were associated with with a worse survival in a total of 95 patients with Adult T-cell leukemia/lymphoma (ATLL). In the same study; poor performance status, high IPI score, presence of B symptoms and low albumin levels were found to be associated with worse survival.

In our study, we found that alloHSCT recipients with increased LDH levels had significantly lower DFS, compared with patients who had normal LDH levels $(\mathrm{p}=0.026)$. The data showed that OS was not found significantly associated with LDH levels prior to HSCT (Figure 1). This result may suggest that elevated LDH levels may reflect increased risk for relapse which mainly predicts DFS. In our laboratory devices, serum LDH levels were determined between 100-245U/L. We determined the cut-off level for abnormality of LDH as $>246 \mathrm{U} / \mathrm{L}$. Some authors have demonstrated that serum LDH levels $>400 \mathrm{U} / \mathrm{l}$ was of significant adverse effect on survival and rate of disease progression in 185 patients diagnosed with Hodgkin's disease [20].

We know that serum LDH levels usually reflect tumor burden in hematological or solid malignancies. However, most of our alloHSCT recipients achieved remission (complete or partial) prior to the transplantation so it is an unexpected manner that they may have high tumor burden. This observation may suggest that high serum LDH levels may reflect high risk for disease relapse regardless with tumor burden. In a study performed by Pui et al. [21]; they found that elevated serum LDH levels were correlated with treatment failure $(p<0.0001)$ in pediatric patients with Acute Lymphoblastic Leukemia (ALL). It was suggested that serum LDH levels could be useful for identifying relapse risk in childhood ALL. Our findings are consistent with findings of previous study in terms of risk stratification for hematological malignancies including serum LDH [22].

Advanced age is considered as a predictive marker for poor prognosis following HSCT. Yet, older patients with AML are also more likely to have intrinsically more resistant leukemias due, to adverse cytogenetic profiles [23]. This association confounds the prognostic importance of age alone. Also several studies have clearly showed poorer survival after HSCT in patients older than 40 years [24,25], while others have found no adverse effect of age in patients younger than 40 years $[26,27]$. In our experience verified by present study; patients with younger than 40 had lower risk for survival compared with patients older than 40 years but this was not statistically significant $(\mathrm{p}>0.05)$. Most of the studies suggest that serum LDH levels might indicate poor prognosis in patients with solid malignancies and lymphomas. However, studies focusing on the probable effect of serum LDH for prognosis in HSCT recipients is too limited. This study could maintain encouraging result for $\mathrm{LDH}$ analysis to determine a prognostic marker in alloHSCT recipients for posttransplant period.
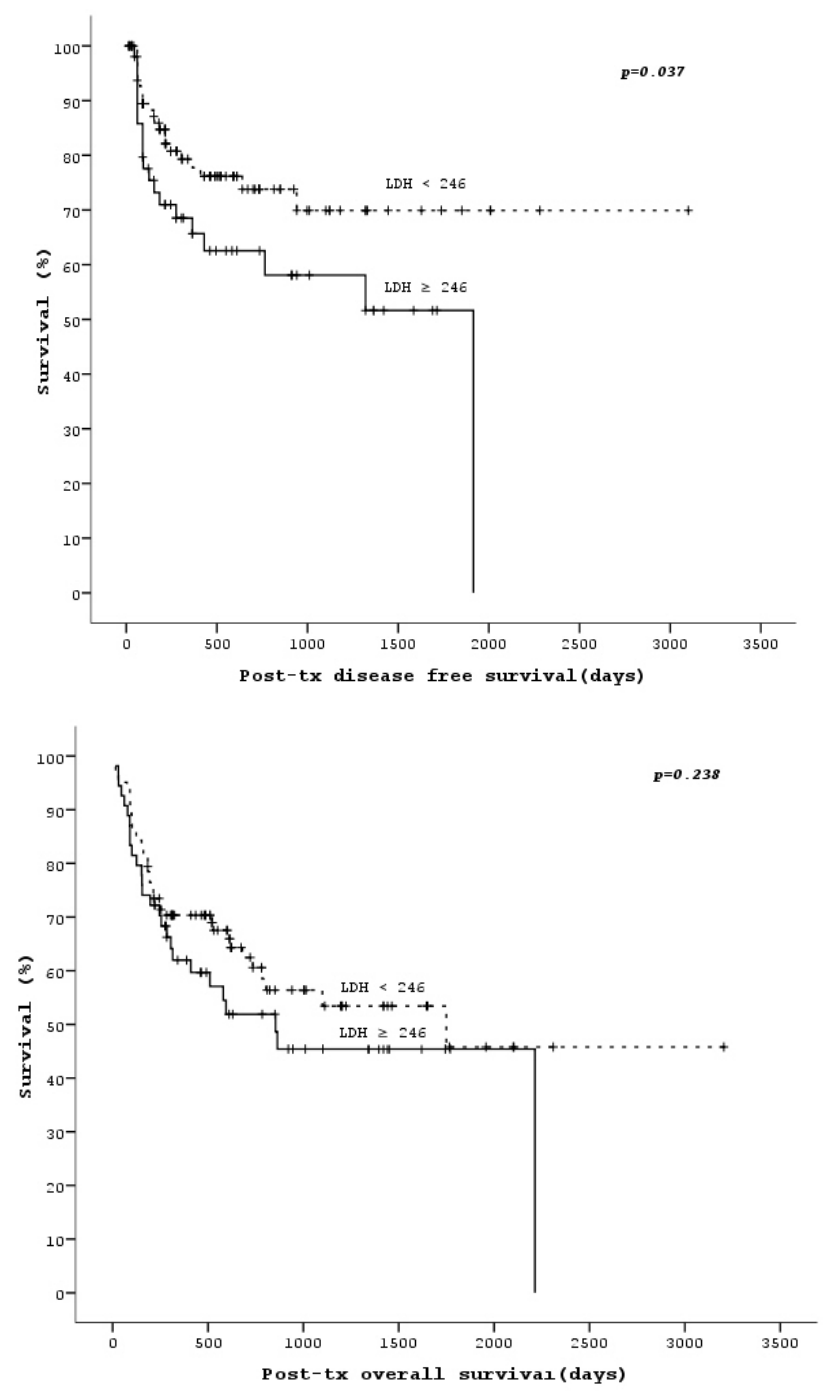

Figure 1: Post-transplant Kaplan-Meier curves for disease-free survival(DFS) and overall survival(OS) of alloHSCT recipients. DFS was statistically longer in patients with $\mathrm{LDH}<246$ compared to patients with $\mathrm{LDH} \geq 246 \quad(p=0.037)$. However, there was no statistically significant difference among groups for OS $(p=0.238)$.

In our study, time-to-transplant interval was found as an important predictor of overall survival (OS) and disease-free survival (DFS) but it was not statistically significant $(\mathrm{p}>0.05)$. This may be due to earlier remission of some patients as a result of first or second-line chemotherapy regimens. It should be noted that chemoresistant patients underwent alloHSCT later than patients who achieved remission in first-line regimens so this may be considered as a disadvantage prior to transplantation. Patients who underwent alloHSCT before 12 months from diagnosis, OS and DFS were found to be longer than patients who underwent alloHSCT longer than 12 months from diagnosis.

In a recent study [28], the prognostic value of serum LDH levels in 465 patients with nasopharyngeal carcinoma (NPC) treated with intensity-modulated radiotherapy was investigated. As a result, they found that elevated serum LDH levels were associated with clinically advanced disease and poor prognosis for OS, DFS and distant metastasis-free survival (DMFS) with a $\mathrm{p}$ value of $<0.001$. Danner et al. [29] performed a study in patients with non-small cell lung cancer 
Citation: Sivgin S, Ozenmis T, Kaynar L, Kurnaz F, Sivgin H, et al. (2012) Predictive Value of Pretransplant Serum Lactate Dehydrogenase (LDH) Levels for Survival in Patients who have undergone Allogeneic Hematopoietic Stem Cell Transplantation (alloHSCT). J Stem Cell Res Ther 2:118. doi:10.4172/2157-7633.1000118

Page 5 of 5

(NSCLC) to evaluate the prognostic significance of serum LDH levels on survival. They found that high serum LDH had a negative impact on long-term survival in NSCLC $(\mathrm{p}<0.001)$.

This study has several limitations as; 1) This is a retrospective study although number of patients enrolled in the study seems to be satisfied. 2) The determination of changes in the levels of LDH before and after transplantation could be more informative for predictive power of serum LDH.

In conclusion, serum LDH levels prior to transplantation may reflect prognostic value for survival in patients who have undergone alloHSCT.

\section{References}

1. Williamson EC, Millar MR, Steward CG, Cornish JM, Foot AB, et al. (1999) Infections in adults undergoing unrelated donor bone marrow transplantation. Br J Haematol 104: 560-568.

2. van Kraaij MG, Verdonck LF, Rozenberg-Arska M, Dekker AW (2002) Early infections in adults undergoing matched related and matched unrelated/ mismatched donor stem cell transplantation: a comparison of incidence. Bone Marrow Transplant 30: 303-309.

3. Altès A, Remacha AF, Sureda A, Martino R, Briones J, et al. (2002) Iron overload might increase transplant-related mortality in haematopoietic stem cell transplantation. Bone Marrow Transplant 29: 987-989.

4. Armand P, Kim HT, Cutler CS, Ho VT, Koreth J, et al. (2007) Prognostic impact of elevated pretransplantation serum ferritin in patients undergoing myeloablative stem cell transplantation. Blood 109: 4586-4588.

5. Kataoka K, Nannya Y, Hangaishi A, Imai Y, Chiba S, et al. (2009) Influence of pretransplantation serum ferritin on nonrelapse mortality after myeloablative and nonmyeloablative allogeneic hematopoietic stem cell transplantation. Bio Blood Marrow Transplant 15: 195-204.

6. Solal-Celigny P, Roy P, Colombat P, White J, Armitage JO, et al. (2004) Follicular lymphoma international prognostic index. Blood 104: 1258-1265.

7. Von Eyben FE, Blaabjerg O, Hyltoft-Petersen P, Madsen EL, Amato R, et al (2001) Serum lactate dehydrogenase isoenzyme 1 and prediction of death in patients with metastatic testicular germ cell tumors. Clin Chem Lab Med 39: 38-44

8. Lassen UN, Osterlind K, Hirsch FR, Bergman B, Dombernowsky P, et al (1999) Early death during chemotherapy in patients with small cell lung cancer: derivation of a prognostic index for toxic death and progression. $\mathrm{Br} \mathrm{J}$ Cancer 79: $515-519$

9. Ferraris AM, Giuntini P, Gaetani GF (1979) Serum lactic dehydrogenase as a prognostic tool for non-Hodgkin lymphomas. Blood 54: 928-932.

10. Hagberg H, Siegbahn A (1983) Prognostic value of serum lactic dehydrogenase in non-Hodgkin's lymphoma. Scand J Haematol 31: 49-56.

11. Holbrook JJ, Liljas A, Steindel SJ, et al. (1975) Lactate dehydrogenase. In: Boyer PD, editor. The enzymes. New York: Academic Press: 191-292.

12. Turen S, Ozyar E, Altundag K, Gullu I, Atahan IL (2007) Serum lactate dehydrogenase level is a prognostic factor in patients with locoregionally advanced nosopharyngeal carcinoma treated with chemoradiotherapy. Cancer Invest 25: 315-321.

13. Glick JH Jr (1969) Serum lactate dehydrogenase isoenzyme and total lactate dehydrogenase values in health and disease, and clinical evaluation of these tests by means of discriminant analysis. Am J Clin Pathol 52: 320-328.

14. Wimazal F, Sperr WR, Kundi M, Vales A, Fonatsch C, et al. (2008) Prognostic significance of serial determinations of lactate dehydrogenase (LDH) in the follow-up of patients with myelodysplastic syndromes. Ann Oncol 19: 970-976.

15. Iwanaga M, Furukawa K, Amenomori T, Mori H, Nakamura H, et al. (1998) Paroxysmal nocturnal haemoglobinuria clones in patients with myelodysplastic syndromes. Br J Haematol 102: 465-474.

16. Oelschlaegel U, Besson I, Arnoulet C, Sainty D, Nowak R, et al. (2001) A standardized flow cytometric method for screening paroxysmal nocturnal haemoglobinuria (PNH) measuring CD55 and CD59 expression on erythrocytes and granulocytes. Clin Lab Haematol 23: 81-90.
17. Mehta J, Gordon LI, Tallman MA, Winter JN, Evens AM, et al. (2006) Does younger donor age affect the outcome of reduced-intensity allogeneic hematopoietic stem cell transplantation for hematologic malignancies beneficially? Bone Marrow Transplant 38: 95-100.

18. Pan L, Beverley PC, Isaacson PG (1991) Lactate dehydrogenase (LDH) isoenzyme and proliferative activity of lymphoid cells--an immunocytochemical study. Clin Exp Immunol 86: 240-245

19. Beltran B, Quiñones P, Morales D, Cotrina E, Castillo JJ (2011) Different prognostic factors for survival in acute and lymphomatous adult T-cell leukemia/ lymphoma. Leuk Res 35: 334-339.

20. Straus DJ, Gaynor JJ, Myers J, Merke DP, Caravelli J, et al. (1990) Prognostic factors among 185 adults with newly diagnosed advanced Hodgkin's disease treated with alternating potentially non-cross resistant chemotherapy and intermediate-dose radiation therapy. J Clin Oncol 7: 1173-1186.

21. Pui CH, Dodge RK, Dahl GV, Rivera G, Look AT, et al. (1985) Serum lactic dehydrogenase level has prognostic value in childhood acute lymphoblastic leukemia. Blood 66: 778-782.

22. Sekeres MA, Stone R (2002) Older adults with acute myeloid leukemia. Current Oncol Rep 4: 403-409.

23. Ferrant A, Labopin M, Frassoni F, Prentice HG, Cahn JY, et al. (1997) Karyotype in acute myeloblastic leukemia: prognostic significance for bone marrow transplantation in first remission: a European Group for Blood and Marrow Transplantation study. Acute Leukemia Working Party of the European Group for Blood and Marrow Transplantation (EBMT). Blood 90: 2931-2938.

24. Frassoni F, Labopin M, Powles R, Mary JY, Arcese W, et al. (2000) Effect of centre on outcome of bone-marrow transplantation for acute myeloid leukaemia. Acute Leukaemia Working Party of the European Group for Blood and Marrow Transplantation. Lancet 355: 1393-1398.

25. Jourdan E, Boiron JM, Dastugue N, Vey N, Marit G, et al. (2005) Early allogeneic stem-cell transplantation for young adults with acute myeloblastic leukemia in first complete remission: an intent-to-treat long-term analysis of the BGMT experience. J Clin Oncol 23: 7676-7684.

26. Suciu S, Mandelli F, de Witte T, Zittoun R, Gallo E, et al. (2003) Allogeneic compared with autologous stem cell transplantation in the treatment of patients younger than 46 years with acute myeloid leukemia (AML) in first complete remission (CR1): an intention-to-treat analysis of the EORTC/ GIMEMA AML10 trial. Blood 102: 1232-1240.

27. Cairo MS, Sposto R, Gerrard M, Auperin A, Goldman SC, et al. (2012) Advanced Stage increased lactate dehydrogenase, and primary site, but not adolescent age ( $>=15$ Years), are associated with an increased risk of treatment failure in children and adolescents with mature B-Cell non-Hodgkin's lymphoma: results of the FAB LMB 96 study. J Clin Oncol 30: 387-393.

28. Zhou GQ, Tang LL, Mao YP, Chen L, Li WF, et al. (2012) Baseline serum lactate dehydrogenase levels for patients treated with intensity-modulated radiotherapy for nasopharyngeal carcinoma: a predictor of poor prognosis and subsequent liver metastasis. Int J Radiat Oncol Biol Phys 82: e359-e365.

29. Danner BC, Didilis VN, Wiemeyer S, Stojanovic T, Kitz J, et al. (2010) Longterm survival is linked to serum LDH and partly to tumour LDH-5 in NSCLC. Anticancer Res 30: 1347-1351. 